\title{
Sciendo
}

HOLISTICA Vol 10, Issue 2, 2019, pp. 51-68

\section{ABID concept in the effect of financial policy on firm value}

\author{
Tri, PURWANI, \\ AKI University, Imam Bonjol No. 15-17 Semarang - Indonesia, \\ tri.purwani@unaki.ac.id
}

\begin{abstract}
The main aim of this research is to test the effect of financial policy on firm value. The research question developed in this research is how the effect of financial policy on firm value by using the concept of ABID? Based on the purpose sampling method there are 26 companies which distribute the dividends successively, so that 26 samples are obtained. Structural equation model with partial least square analysis tool is used to prove empirically the effect of each variables and the hypothesis testing. The findings of the study show that investment decisions have negative effect on dividend policy, but not significant. Investment decisions have significant positive effects on funding decisions and firm value. Dividend policy has significant positive effect on funding decisions and firm value. Funding decisions significantly influence the firm value positively. The results of this study reject the pecking order theory.
\end{abstract}

Keywords: financial policy; firm value; Tobin's $Q$

JEL Classification: G11

\section{Introduction}

In the long run, the company's goal is to increase the firm value through the implementation of financial policies consisting of investment decision, funding decision and decision about dividend policy. Investment decision is related to the amount of investment made by the company. The high investment will reduce the amount of cash dividend that will be received by shareholders.

Some investors assume that the dividend received at present time is more valuable than capital gain obtained in the future, therefore in unbalanced information condition (asymmetric information) manager can use strategies in dividend policy to counteract issues that are not expected by company in the future. Funding decisions related to debt are instruments that are very sensitive to firm value. 
This is in accordance with the trade-off theory which states that at the time before reaching the maximum point, debt is cheaper than stocks because of the tax saving (tax shield). The relatively large corporate funding decision needs to be supported by the company's ability to make profit.

The manager will take the best action for the company by maximizing the firm value so that the shareholders' prosperity can be achieved. However, the tendency of professionals are trying to prosper themselves, for example by doing expansion that can increase their status or salary, asking for more facilities and the possibility of making risky decisions by creating high debt to increase the firm value. Such behaviors are sometimes in contrast with the owner of the company, who has different interests.

The researches related to the influence of financial policy with firm values have been carried out by several researchers, but they provide different findings, so it is still interesting to study. Mursalim, Hendragunawan, Nur Alamzah \& Abdulah Sanusi (2015) found evidence that investment decision has positive effect on company profitability. The increase in investment will increase the firm value. This reinforces the opinion that if the level of investment in a company is high, it will increase investor confidence in the company because investment growth can be perceived as good news for investors.

The results of the research conducted by Sorin Gabril (2016), found that dividend policy affected the firm value. On the other hand, the results of Yulia (2017) found that dividend policy did not affect the firm value. Muhammad W. R., Shaheed B.B. (2013) succeeded in finding evidence that the use of leverage has negative effect on firm value.

Another study conducted by Hasnawati (2005) found that investment decision, funding decision, and dividend policy partially have positive effect on firm value. Dividend policy affects the firm value directly and indirectly investment decision affects the firm value through dividend policy and funding decision.

In addition, investment decision variable in this study uses the concept of investment decisions as decision concerning resource allocation of funds in total assets owned by the company, both short-term assets and long-term assets. Therefore the investment decision variable in this study can be said using new concept called assets-based investment decision (ABID) which is measured by using total assets.

This is based on the consideration that by using assets-based investment decision, it is able to show the actual assets where assets are the assets used for company operations. With this background, the research question developed is 
how the effect of financial policy on firm value by using the concept of assetsbased investment decision.

\section{Literatur Review}

\subsection{Pecking Order Theory}

Smart, Megginson, and Gitman (2004, pp. 458-459), there is a sequence (hierarchy) scenario in selecting sources of funding, namely:

- Companies prefer using sources of funds from within or internal funding to using external funding. The internal funds are obtained from retained earnings resulted from the company's operational activities.

- If external funding is required, the company will choose the first start of the safest securities, i.e the lowest debt risk, to more risky debt, hybrid securities such as convertible bonds, preferred stock, and the last is common stock.

- There is a constant dividend policy, namely the company will determine the amount of constant dividend payments, not affected by how much the company gains or loses.

- To anticipate a shortage of cash supply due to a constant dividend policy and fluctuation of profit level, as well as investment opportunities, then the company will take a smooth investment portfolio available. Pecking order theory does not indicate the target of capital structure. Pecking order theory explains the sequence of funding. Financial manager does not take into account the optimal debt level. Funding needs are determined by investment needs. This Pecking order theory can explain why companies that have high level of profit in fact have small level of debt.

\subsection{Trade off Theory}

Myers (2001), stated that "companies will be indebted to a certain level of debt, where tax savings (tax shields) from the additional debt equals with the cost of financial distress". An optimal level of debt is achieved when tax savings (tax shields) reach the maximum amount to the costs of financial distress. According to Myers pecking order theory is "Companies with high levels of profitability are actually low in debt, because companies with high profitability have abundant internal funding sources." In this pecking order theory there is not optimal capital structure. 
Specifically, companies have a sequence of preferences (hierarchy) in the use of funds. The implication of Pecking order theory is: a). Companies that have high profits use debt in low amounts and vice versa. Companies with high profit allow them to use retained earnings as the source of company funding. The reason is, internal funding cost is cheaper than external cost; b).

If the company's cash is in deficit and requires external funds, the external funding source chosen is debt and the last alternative is stock.

\subsection{Signaling Theory}

Companies with favorable prospects seek every new capital needed in other ways, including the use of debt that exceeds the normal capital structure target. Companies with less profitable prospects will tend to sell their shares. The signal media that are commonly used by management are through financial policies set by the company. Funding decision is a form of delivering information through signal. With the existence of asymmetric information between management and investor, the signal is an important factor in obtaining funding sources.

\subsection{Firm Value}

Firm value is certain condition that has been achieved by a company as an illustration of public trust in the company after going through an activity process for several years, namely since the company was established until now. The increase in the firm value is an achievement, which is in accordance with the wishes of the owners, because with the increase in the firm value, the welfare of the owners will increase, and this is the duty of the manager as an agent who has been given the trust by the owner.

The manager's policy will be crucial in achieving optimal results to increase the firm value. Therefore managers must be able to determine policies that can effectively increase the firm value. Tobin's $Q$ as measurement of firm value illustrates that the higher the Tobin's $Q$ the higher the firm value, so that investors is getting more interesting.

\subsection{Financial Policy}

Financial manager must find and use optimal funding sources, whether seeking funds from internal (retained earnings and depreciation) or external 
(equity and debt) or even both. The right funding decision will affect the company's performance, because each funding source has different advantages and risks. The issue regarding investment is related to other matters, including the problem of funding sources for investment, the economic life of the investment, and the most important is the expected return of the investment. If we make mistake in making investment policy, the firm value will decrease.

However, this increase in investment will have impact on the amount of dividends distributed to the shareholders. The high investment of the company will reduce the amount of cash dividend that can be given. If the dividend policy is in accordance with management's estimation of investment opportunities in the future, the company can maintain stable dividend and obtain the required equity funding through internal sources.

This finding explains that investment decisions are dominant decisions that will influence other decisions such as funding and dividends. The three financial decisions made by the company illustrate the various measures of financial decisions (investment, funding, and dividend) allowing some researchers to use various ratios as the proxy for financial decision.

\subsection{Assets Based Investment Decision (ABID)}

In general, theories related to investment management are experiencing rapid development. At least there are five theories that can be said to underlie investment management. The five theories are Portpholio Theory, Capital Market Theory, Securities Assessment, Market Efficiency and Derivative Securities Assessment. IOS provides broader clues where the firm value depends on the company's future expenses.

There are several IOS proxies used in several previous studies, namely:

(1) Price-based proxies which based on the difference between asset and stock market value. So this proxy is very dependent on stock prices. This proxy is based on an idea stating that the company's growth prospects are partially expressed by stock price, then company that has high growth will have relatively higher market value than the assets owned (assets in place). Therefore, a growing companies should be linked to the highest market capitalization ratio for book value on its asset or equity.

(2) Investment-based IOS proxies indicate that investment activity is positively related to companies IOS. 
Investment decision in this study used the concept of investment decision as decision concerning the allocation of funding sources on the total assets owned by the company, both short-term assets and long-term assets. The investment decision variable in this study used assets-based investment decision (ABID) which are measured by using total assets. This is based on the consideration that by using assets-based investment decision, it is able to show actual asset growth where assets are the assets used for the company operations.

\subsection{Hypothesis Development and Research Model}

\subsubsection{The Influence of Investment Decision on Dividend Policy}

The relationship between investment decisions and dividend policy can be identified through the company's cash flow, i.e the greater the amount of investment in a given period, the smaller the dividend will be given. The new issue market is one way to reduce agency costs, because it means there is an increase in oversight of managers by the shareholders whose numbers are more or greater control rights for the shareholders. Therefore, companies that have low growth option will be reluctant or rarely do new issue market.

Investment decision will affect the success of achieving company goal (Gitman, 2000; Brealy \& Myers; 2000). The firm value formed through stock market value indicator is strongly influenced by investment opportunities and discretionary expenditure in the future. For this reason, increasing investment will increase the firm value. Based on the literature support as described above, the hypothesis presented in this study is as follows:

Hypothesis 1: Assets-based investment decision negatively affects the dividend payout ratio.

\subsubsection{The Influence of Investment Decision on Funding Decision}

The greater the fund owned by the company, the greater the investment opportunities that can be made by the company. Funding in this study is external funding (debt). Companies with over investment problem generally have large assets in place. Large assets in place within a company can be used as collateral for debt collection policy, thus allowing the company to take high level of debt.

Empirical evidence shows the relationship between investment decisions and funding decision. Moyen (2004); Almeida, Campello, and Weisbach (2004) show that there is a link between liquidity and investment decisions in companies 
in the United States. The same thing was also found by Hoshi, Kashyap, and Scharfstein (1991) in Japan.

Based on the literature support as described above, the hypothesis presented in this study is as follows:

Hypothesis 2: Assets-based investment decision has positive effect on the debt to equity ratio.

\subsubsection{The Influence of Investment Decision on Firm Value}

Firm value formed through stock market value indicator is strongly influenced by investment opportunities. Investment expenditure will influence growth, and increasing the stock price as firm value indicator. The firm value will increase when the present value of the company investment has positive growth opportunity. The firm value will decrease if the present value of the company's investment has negative growth opportunity (Ross et. al, 1999). According to Ang (1997), the greater the assets, the greater the operational results produced by a company. Based on the literature support as described above, the hypothesis presented in this study is as follows:

Hypothesis 3: Assets-based investment decision has positive effect on firm value.

\subsubsection{The Influence of Dividend Policy on Funding Decision}

Companies with high level of debt will try to reduce the agency cost of debt by reducing debt, so that to finance its investment, funding from internal cash flow is used. The researchers who were successfully found evidence that the influence between dividend and debt was positive and significant, among others were Emery and Finnerty (1997, p. 568).

The greater the fund the company can get from debt, the more likely the shareholders will get benefit from dividend. The company owners tend to like the company to add external funding because it can increase their income so that it can improve the welfare of the company owners.

Risk adjustments with shareholder prosperity and the achievement of optimal structures are predicted to have positive relationship. It is also mentioned that the significant effect of dividend on debt in minimizing agency costs. Noronha et.al (1996) find simultaneous unrelated relationships between dividend and capital structure. Megginson (1997) states that free cash flow hypothesis can be 
used to predict the interdependence relationship between debt and dividend. Dividend affects debt with positive relationship. Companies that distribute large amounts of dividends require additional funds through debt to finance their investments. Based on the literature support as described above, the hypothesis presented in this study is as follows:

Hypothesis 4: Dividend payout ratio has positive effect on debt to equity ratio.

\subsubsection{The Influence of Dividend Policy on Firm Value}

The survival and the growth of the company need to be considered in the dividend distribution decision. Thus profit is not entirely distributed in the form of dividend but it needs to be set aside for reinvestment. There are several parties who have the same interest related to the dividend policy, namely the interests of the shareholders, bondholders and the company itself. The amount of the dividend that will be paid by the company depends on the dividend policy of each company, so that management consideration is badly needed.

Some studies have suggested how dividend can affect the firm value, provide results that are mutually contradictory, so that it often leads to the doubts of management and other parties who have interest in the company.

Dividend contains information or as signal of the company's prospects. Announcement of the increased dividend has increased stock return, and can be used to counter issues that the company does not expect in the future. Dividend policy is confirmed through dividend payout ratio and dividend yield (Kallapur \& Trombley, 1999).

Dividend policy is an important corporate action that must be carried out by the company. The policy can determine how much profit the shareholders will get. The profits that the shareholders will get will determine the welfare of the shareholders which is the company's main objective. The greater the dividend distributed to shareholders, the performance of the issuer or company will be considered even better and in the end the company that has good performance is considered profitable and of course the assessment of the company will be even better, which is usually reflected through the company's stock price level. Based on the literature support as described above, the hypothesis presented in this study is as follows:

Hypothesis 5: Dividend payout ratio has positive effect on firm value. 


\subsubsection{The Influence of Funding Decision on Firm Value}

One important decision that must be made by the manager in relation to the continuity of the company's operations is debt or capital structure decision. Capital structure shows the composition of internal and external capital. Funding taken by this company can affect the firm value (Park \& Evan, 1996). If the internal funding source is insufficient, the company will take outside funding sources, one of which is debt. Funding through debt will result in the effect of tax deductible, which means that companies with debt will pay interest on loans that can reduce taxable income, so that it can benefit shareholders.

Frank and Goyal (2000) state that large companies will add debt to support dividend payment. The higher the level of debt the more funds available to pay higher dividend because it will give positive signal and cause the firm value to rise. Increased debt is interpreted by outsiders about the company's ability to pay obligation in the future or the existence of low business risk, it will be responded positively by the market (Brigham, 2002).

Leverage is a proxy of the risk faced by shareholders and becomes agency fee in a conflict of interest between shareholders and creditors. Increased debt is interpreted by outsiders about the company's ability to pay obligations in the future or the existence of low business risk, it will be responded positively by the market (Brigham, 1999). Based on the literature support as described above, the hypothesis presented in this study is as follows:

Hypothesis 6: Debt to equity ratio has positive effect on firm value

The research model that shows the relationship between financial policy and firm value is presented as seen in figure 1.

Figure 1. Research Model

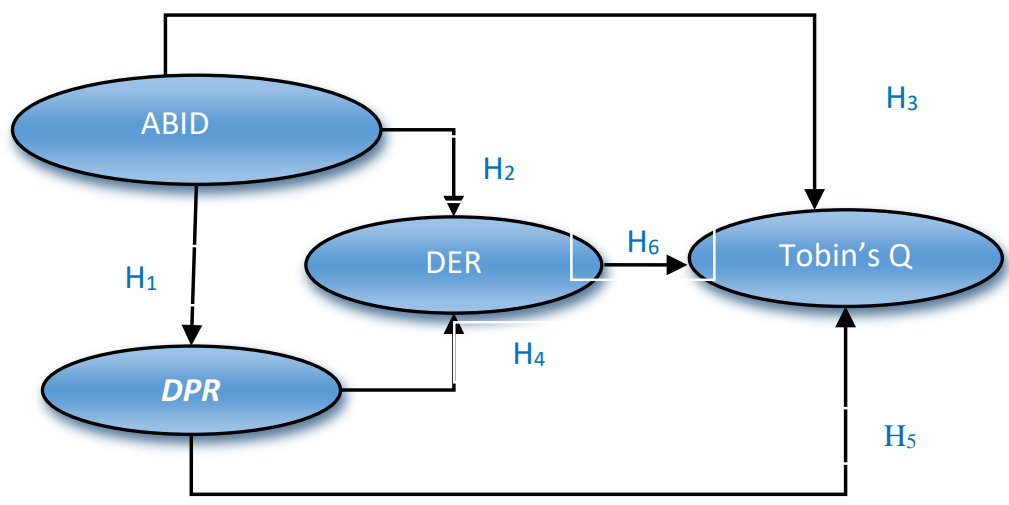

Source: Tri Purwani, 2016 


\section{Material and Method}

\subsection{Population and Sample}

The population in this research were all non-financial companies listed on the Indonesia Stock Exchange during the financial reporting period of 2013-2016. According to the data contained in the Indonesian Capital Market Directory (ICMD), by using the purposive sampling method there were 26 companies that distributed dividends successively to obtain 26 sample companies.

\subsection{Technique of Analysis}

Based on the empirical model described above, the data were analyzed using structural equation model. Structural equation model is more suitable for the analysis in this study because SEM is able to estimate several equations separately, but interconnected with multiple regression equation simultaneously and its ability to present latent variables (Ghozali 2008).

\section{Results}

\subsection{The Testing of Empirical Model}

Based on the research model presented in figure 1, the structural equation of the research model is mathematically as follows:

$$
\begin{aligned}
& D P R_{i}=\gamma_{1.1} A B I D_{i}+\zeta_{1} \\
& D E R_{i}=\gamma_{2.1} A_{B I D}+\beta_{2.1} D R_{i}+\zeta_{2} \\
& \text { Tobin's } Q_{i}=\gamma_{3.1} A B I D_{i}+\beta_{3.1} D P R_{i}+\beta_{3.2} D R_{i}+\zeta_{3}
\end{aligned}
$$

\subsection{The Goodness of Fit Model Based on R-Square for Each Endogenous Variables}

This model evaluation aims to explain the structural model of each endogenous variables. This study has three structural equations. The results of the calculation and evaluation of R-Square for each endogenous variables are shown in table 1 below.

Table 1. $R$-Square Value

\begin{tabular}{lr}
\hline Variable & $R$-Square \\
\hline DER & .369072 \\
DPR & .032157 \\
Tobin'q & .694746 \\
\hline
\end{tabular}

Source: Smart PLS 
In the table 1 it is explained that the coefficient value of the determination $\left(R^{2}\right)$ of the firm value endogenous variable (Tobin's $Q$ ) of 0.695 means that the structural model formed in equation 3 is good category model and $69.5 \%$ variation of firm value can be explained by variations of variables such as debt to equity ratio, dividend payout ratio and assets-based investment decision.

The coefficient of determination $\left(R^{2}\right)$ for the debt to equity ratio variable is 0.369 which means that the structural model formed in equation 2 is a moderate category model, and $36.9 \%$ variation of debt to equity ratio can be explained by variations of variables such as dividend payout ratio and assets-based investment decision.

The coefficient of determination $\left(\mathrm{R}^{2}\right)$ for the dividend payout ratio variable is 0.032 which means that the structural model formed in equation 1 is a model with very weak category. The coefficient of determination $\left(R^{2}\right)$ of 0.032 indicates that only $3.20 \%$ of the dividend payout ratio can be explained by variations of the assets-based investment decision variable.

\subsection{The Goodness of Fit Model Based on f-Square for Each Endogenous Variables}

This model evaluation aims to assess the effect of exogenous variables on endogenous variables at the structural level.

Table 2. f-Square Value of Tobin'Q Latent Variable Equation

\begin{tabular}{lrrr}
\hline Predictor & $\mathrm{R}^{2}$ Included & $\mathrm{R}^{2}$ Exclude & \multicolumn{1}{c}{$\mathrm{F}^{2}$} \\
\hline DER & .694746 & .682104 & .041415 \\
DPR & .694746 & .637587 & .187251 \\
ABID & .694746 & .476510 & .714932 \\
\hline
\end{tabular}

Source: Smart PLS

The $\mathrm{f}$-Square value of the Tobin's $\mathrm{Q}$ latent variable equation in equation 3 is shown in table 2 above, that the predictor of debt to equity ratio has an effect size $\left(f^{2}\right)$ of 0.041415 . This means that predictor of debt to equity ratio has weak effect on the level of structural equation, because the value is below 0.02 . The dividend payout ratio predictor has effect size $\left(\mathrm{f}^{2}\right)$ of 0.187251 .

This means that the predictor of dividend payout ratio has sufficient effect on the level of structural equation, because the value is above 0.15 . The predictor of assets-based investment decision has effect size $\left(f^{2}\right)$ of 0.714932 . This means that predictor of assets-based investment decision has great effect on the level of structural equation, because the value is above 0.35 . 
4.4. The Goodness of Fit Model Based on Q-Square for Each Endogenous Variables

This model evaluation is used to prove whether the model has predictor relevance value or not. The results of the analysis using Partial Least Square software and running through blindfolding are presented in Table 3 below.

Table 3. Q-Square Value of Each Equation Model

\begin{tabular}{lr}
\hline Predictor & $\mathrm{Q}^{2}$ \\
\hline DPR & .003684 \\
DER & .058625 \\
Tobin's Q & .351506 \\
\hline
\end{tabular}

Source: Smart PLS

Table 3 above shows that the three equation models in the research model, i,e equation 1 (DPR as the dependent variable), Equation 2 (DER as the dependent variable), and Equation 3 (Tobin's $Q$ as the dependent variable), have predictive relevance value, because the value of $\mathrm{Q}$-Square for the three models is greater than zero (Ghozali, 2008 and Henseler et.al, 2009).

\subsection{The Testing of Hypothesis}

The value of Inner Model and the t-statistic structural model of the above study can be seen in table 4 . Based on the table 4 , the hypothesis is tested according to the hypothesis proposed in this study.

Table 4. Inner Model and t-statistics

\begin{tabular}{lccccc}
\hline & $\begin{array}{c}\text { Original } \\
\text { Sample (Q) }\end{array}$ & $\begin{array}{c}\text { Sample } \\
\text { Mean } \\
(\mathrm{M})\end{array}$ & $\begin{array}{c}\text { Standard } \\
\text { Deviation } \\
\text { (STDEV) }\end{array}$ & $\begin{array}{c}\text { Standard } \\
\text { Error } \\
(\text { STERR) }\end{array}$ & $\begin{array}{c}\text { T Statistic } \\
\text { (O?STERR) }\end{array}$ \\
\hline DER $\rightarrow$ Tobin's Q & 0,141550 & 0,135005 & 0,068416 & 0,068416 & $2,068961^{* *}$ ) \\
DPR $\rightarrow$ DER & 0,227809 & 0,225074 & 0,083937 & 0,083937 & $2,714042^{*}$ ) \\
DPR $\rightarrow$ Tobin's Q & 0,252507 & 0,258949 & 0,105711 & 0,105711 & $\left.2,388654^{* *}\right)$ \\
ABID $\rightarrow$ DER & 0,594306 & 0,595726 & 0,088646 & 0,088646 & $\left.6,704229^{*}\right)$ \\
ABID $\rightarrow$ DPR & $-0,034456$ & $-0,039956$ & 10.20 & 0,089226 & 0,386161 \\
ABID $\rightarrow$ Tobin'sQ & 0,635058 & 0,627246 & 10.20 & 0,086344 & $\left.7,355007^{*}\right)$ \\
\hline
\end{tabular}

$* *$, and * denote significance at the $5 \%$, and $1 \%$ levels

Source: Smart PLS 


\section{Discussion, and Conclusions}

\subsection{Discussion}

\subsubsection{The Testing of Hypothesis 1}

Hypothesis 1 states that the assets-based investment decision negatively affects the dividend payout ratio. The results of statistical testing using Partial Least Square in table 4 shows that the relationship between assets-based investment decision and dividend payout ratio has coefficient of regression with negative sign that is equal to -0.034456 with $t$ statistics of 0.386161 .

The coefficient with negative sign indicates that the relationship between assets-based investment decision and dividend policy is in accordance with the research hypothesis.

However, the hypothesis stating that the assets-based investment decision negatively affects the dividend payout ratio is not proven, because the $t$ statistics value is smaller than the $t$ table value at significance level of $\alpha=10 \%(1,645)$.

This is consistent with the research of Smith and Watts (1992), which states the relationship between investment policy and dividend policy can be identified through the company's cash flow.

The greater the amount of investment in a certain period, the smaller the dividend given, because the growing company is identified as a company with low free cash flow (Jensen 1986 in Smith and Watts 1992).

Levy and Sarnat (1990) argued that companies that have investment opportunities will prefer choosing internal funding to external, because internal funding is cheaper. As a result, dividend policy emphasizes smaller dividend payments.

\subsubsection{The Testing of Hypothesis 2}

Hypothesis 2 states that the assets-based investment decision has positive effect on the debt to equity ratio (DER). The results of statistical testing using Partial Least Square in Table 4 shows that the relationship between assets-based investment decision and debt to equity ratio has regression coefficient with positive sign of 0.594306 with t-statistics of 6.704229 .

The regression coefficient with positive sign indicates that the relationship between assets-based investment decision and debt to equity ratio is in 
accordance with the research hypothesis. The higher the level of investment issued by the company, the greater the debt to equity ratio.

The $t$-statistics value of 6.704229 is greater than $t$ table at significance level of $\alpha=1 \%(2,576)$. Therefore the research hypothesis which states that assetsbased investment decision has positive effect on the debt to equity ratio is proven.

\subsubsection{The Testing of Hypothesis 3}

Hypothesis 3 states that assets-based investment decision has positive effect on firm value. The results of statistical testing using Partial Least Square in table 4 shows that the relationship between assets-based investment decision and firm value has regression coefficient with positive sign of 0.635058 with t-statistic of 7.355007 .

The regression coefficient with positive sign indicates that the relationship between assets-based investment decision and firm value is in accordance with the research hypothesis.

The higher the investment made by the company, the higher the firm value. The t-statistic value of 7.355007 is greater than t table at significance level of $\alpha=$

$1 \%(2,576)$. Therefore, the research hypothesis which states that assets-based investment decision has positive effect on firm value is proven.

\subsubsection{The Testing of Hypothesis 4}

Hypothesis 4 states that the dividend payout ratio has positive effect on the debt to equity ratio. The results of statistical testing using partial least square in table 4 shows that the relationship between dividend payout ratio and debt to equity ratio has regression coefficient with positive sign of 0.227809 with tstatistics of 2.714042 .

The regression coefficient with positive sign indicates that the relationship between the dividend payout ratio and the debt to equity ratio is in accordance with the research hypothesis. The higher the dividend payout ratio, the higher the debt to equity ratio.

The $t$-statistic value of 2.714042 is greater than $t$ table at significance level of $\alpha=1 \%(2,576)$. Therefore the research hypothesis which states that the dividend payout ratio has positive effect on the debt to equity ratio is proven.

The results of the research conducted by Aasia Asif, Waqas Rasool and Yasir Kamal (2011), dividend payment variables have positive and significant influence 
on leverage. The results of this study support pecking order theory, where in financing, companies based on the order of retained earnings, then debt and the last is the emission of new shares.

\subsubsection{The Testing of Hypothesis 5}

Hypothesis 5 states that the dividend payout ratio has positive effect on firm value. The results of statistical testing using partial least square in table 4 shows that the dividend payout ratio with firm value has regression coefficient with positive sign of 0.252507 with $\mathrm{t}$-statistic of 2.388654 .

The regression coefficient with positive sign indicates that the relationship between dividend payout ratio and firm value is in accordance with the research hypothesis. The higher the dividend payout ratio, the higher the firm value.

The $t$-statistic value of 2.388654 is greater than $t$ table at significance level of $\alpha=5 \%$ (1.960). Therefore, the research hypothesis which states the dividend payout ratio has positive effect on the firm value is proven.

So, dividend has or contains information (informational content of dividend) or as sign of company prospect. If the company increases dividend payments, it might be interpreted by investors as signal of management's expectation of future improvement in the company's performance.

Therefore dividend has an influence on the firm value. The increase of dividend is made to strengthen the company's position in seeking additional funds from the capital market and banking. Dividend contains information or as signal for the company's prospect (Roseff, 1982). Roseff's opinion was supported by the Asquith and Mullins research (1983) that the announcement of increased dividend had increased stock return, and could be used to counter issues that the company did not expect in the future.

The results of research conducted by Khadija Farrukh, Sadia Irshad, Maria Shams Khakwani, (2017) suggested that dividend payment variables had positive and significant influence on the firm value.

\subsubsection{The Testing of Hypothesis 6}

Hypothesis 6 states that debt to equity ratio has positive effect on firm value. The results of statistical testing using partial least square in table 4 shows that the 
relationship between the debt to equity ratio and firm value has regression coefficient with positive sign of 0.141550 with t-statistic of 2.068961 .

The regression coefficient with positive sign shows that the relationship between debt to equity ratio and firm value is in accordance with the research hypothesis. The higher the debt to equity ratio, the higher the firm value. The tstatistic value of 2,068961 is greater than t table at significance level of $\alpha=5 \%$ $(1,960)$. Therefore, the research hypothesis which states that debt to equity ratio (DER) has positive effect on firm value is proven.

\subsection{Conclusion}

Based on the goodness of fit, the research model is worth testing the research hypothesis with determination coefficient $\left(R^{2}\right)$ of 0.695 . This shows that only $69.5 \%$ variation of firm value that can be explained by variations of variables such as funding decision, dividend policy, and assets-based investment decision.

The predictive relevance ( $Q$-Square) value of the empirical model is greater than zero that is equal to 0.351506 . This shows that the model has predictive relevance value.

Based on the hypothesis testing, it can be concluded that first, the assetsbased investment decision affects the dividend policy (divident payout ratio) negatively. The direction of the relationship is as expected and in accordance with most existing theories, however this relationship is not significant. The argument for rejecting the hypothesis is that investment opportunities are not financed with retained earnings, but they are financed by other funding sources.

Second, the assets-based investment decision influences the funding decision (debt to equity ratio) positively and significantly.

Third, the assets-based investment decision has positive and significant effect on firm value positively. This research indicate that high investment is a signal of the company's revenue growth in the future. The signal will be considered as good news by investors which will affect investors' perception on the company's performance which will ultimately affect the firm value.

Fourth, dividend policy (dividend payout ratio) affects the funding decision (debt to equity ratio) positively and significantly. The greater the dividends paid by the company, the higher the company's funding needs. 
Fifth, dividend policy (dividend payout ratio) affects the firm value positively and significantly. The results of this study prove that the increase in dividend payments is seen as a signal that the company has good prospect.

Sixth, the funding decision (debt to equity ratio) affects the firm value positively and significantly. This means that the greater the company uses debt, the greater the firm value. The results of this study reject the pecking order theory, but support the trade-off theory, where to finance investments issued, the company does not use internal funds first, but it is done by increasing its debt ratio.

\section{References}

[1] Aasia A., Waqas R., \& Yasir K. (2011). Impact of financial leverage on dividend policy: Empirical evidence from Karachi Stock Exchange-listed companies, African Journal of Business Management Vol. 5(4), pp. 1312-1324.

[2] Almeida, H., Campello, M., \& Weisbach, M. S. (2004). The cash Flow Sensitivity of Cash. Journal of Finance, Vol. LIX, no. 4: pp. 1777-1804.

[3] Asquith, P. \& Mullins, Jr. D.W. (1983). The Impact of Initiating Dividend Payments on Shareholders Wealth. Journal of Business, Vol. 56, No. 1, pp. 77-96.

[4] Brigham, E., \& Ehrhardt M. (2002). Financial Management-Theory and Practise, Tenth edition, Thamson Learning, Shouth Western.

[5] Emery, D.R. \& Finnerty, J.D. (1997). Corporate Financial Management, International Edition, Printice Hall Inc.

[6] Frank, M., \& Goyal, V. (2003). Testing the Pecking Order Theory of Capital Structure, Journal of Financial Economics, 67, pp. 217-248.

[7] Gitman J. L. (2003). Principal of Managerial Finance. Edisi 10, Pearson Education International.

[8] Gozali, I. (2008). Structural Equation Modeling Metode alternatif dengan Partial Least Square. Diponegoro University.

[9] Kallapur, S. \& Trombley, M.A. (1999). The Assosiation between Investment Opportunity Set Proxies and Realized Growth. Journal of Business Finance and Accounting, 26, Vol. 3, hal. pp. 505-519.

[10] Khadija Farrukh, Sadia Irshad, Maria Shams Khakwani, (2017). Impact of dividend policy on shareholders wealth and firm performance in Pakistan, Journal Cogent Business \& Management, Volume 4, (1).

[11] Megginson, W.L. (1997). Corporate Finance Theory. Addison-Wesley Educational Publisher, Inc.

[12] Moyen, N. (2004). Investment-Cash Flow Sensitivities: Constrained versus Unconstrained Firms. Journal of Finance, Vol. LIX, no. 5, pp. 2061-2092.

[13] Muhammad W. R., \& Shaheed B.B. (2013). Affect of financial leverage on firm performance. Empirical evidence from Karachi Stock Exchange. Munich Personal RePEc Archive. 
[14] Mursalim, H., Nur A., \& Abdullah S. (2015). Financial Decision, Innovation, Profitability and Company Value: Study on Manufacturing Company Listed in Indonesian Stock Exchange. Information Management and Business Review, Vol. 7, No. 2, pp. 72-78.

[15] Noronha, G.M., Shome, D.K., \& Morgan, G.E. (1996). The Monitaring Rationale for Dividend and Interactions of Capital Structure and Dividend Decission. Journal of Banking and Finance, April, pp. 439-454.

[16] Park, K. W. \& Evan, J. (1996). Firm Value, Free Cash Flow and Financial Decision: Eviden from Japan. University of Illinois Urbana Champaign and Curtin University of Technology Australia.

[17] Ross, S.A. (1997). The Determination of Financial Structure: The Incentive Signaling Approach, The Bell Journal of Economics, Vol. 8, pp. 23-40.

[18] Smart, S. B., Megginson, W. L., \& Gitman, L.J. (2004). Corporate Finance. Thomson, SouthWestern.

[19] Sorin G., \& Cuza, A.I. (2016). The Impact Of Dividend Policy On Firm Value. A Panel Data Analysis of Romanian Listed Firms. Journal of Public Administration, Finance and Law. Issue 10, 2016.

[20] Efni, Y. (2017). The Mediating Effect of Investment Decisions and Financing Decisions on the Effect of Corporate Risk and Dividend Policy against Corporate Value. Investment Management and Financial Innovations, Volume 14, Issue 2. 